\title{
Cefixime in the treatment of uncomplicated multi-drug resistant Salmonella typhi septicaemia in children
}

\author{
N.I. Girgis ${ }^{1}$, R. Franck ${ }^{1}$, Y. Sultan ${ }^{2}$ L. Farid ${ }^{1}$
}

\begin{abstract}
Abstrak
Timbulnya jenis kuman Salmonella typhi yang resisten terhadap berbagai jenis antibiotika yang lazim dipergunakan untuk pengobatan demam tifoid, menyebabkan kurangnya pilihan antibiotika yang dapat dipergunakan terhadap penyakit infeksi yang disebabkan oleh kuman ini, terutama karena adanya larangan penggunaan kuinolon pada penderita anak-anak. Pada penelitian awal yang dilakukan secara acak dan terbuka, dilakukan suatu studi perbandingan efektivitas dari sefiksim dengan seftriakson atau aztreonam untuk demam tifoid yang tidak disertai suatu penyulit pada penderita anak-anak. Dari sejumlah 165 penderita anak-anak dengan demam tifoid yang diikutsertakan dalam penelitian, pada 124 diantaranya didapatkan hasil biakan yang positif untuk kuman S. typhi. Limapuluh anak mendapat pengobatan dengan sefiksim $(7,5 \mathrm{mg} / \mathrm{kg} /$ dosis, per oral dua kali sehari selama 15 hari), 43 anak mendapat terapi seftriakson $(50-70 \mathrm{mg} / \mathrm{kg} /$ dosis, intra muskuler (IM) sekali sehari selama 5 hari) dan 31 anak memperoleh pengobatan dengan aztreonam (50-70 mg/kg/dosis setiap 8 jam IM selama 7 hari). Tidak dijumpai adanya kegagalan secara mikrobiologis pada semua kelompok. Tetapi terdapat 5-6\% angka kekambuhan pada setiap kelompok pengobatan. Pada penelitian terbuka selanjutnya, sefiksim (20 mg/kg/dosis, per oral sekali sehari selama 8 hari) diberikan pada 60 anak dengan umur 3-16 tahun dengan hasil biakan kuman S. typhi yang resisten terhadap berbagai jenis antibiotika, 95\% (57/60) anak mengalami penyembuhan secara mikrobiologis dan hanya seorang pasien yang mengalami kekambuhan dalam waktu 4 minggu setelah pengobatan. Toleransi anak-anak terhadap sefiksim ternyata cukup baik. Hasil penelitian ini menunjukkan bahwa sefiksim merupakan suatu pengobatan alternatif yang efektif untuk pengobatan demam tifoid pada anak-anak.
\end{abstract}

\begin{abstract}
The common occurrence of Salmonella typhi resistant to most antibiotics typically used for treatment of typhoid fever has limited therapeutic options for infections caused by this organism especially in children due to the restriction of the use of quinolones. Initially, we conducted a randomized open label study testing the efficacy of Cefixime to Ceftriaxone or Aztreonam in the treatment of uncomplicated typhoid fever in children. Of the 165 enrolled with clinical typhoid fever, 124 were culture positive for $\mathrm{S}$. typhi, fifty children were treated with Cefixime ( $7.5 \mathrm{mg} / \mathrm{kg} /$ dose orally twice daily for 15 days), 43 children with ceftriaxone (50-70 mg/Kg/dose given intramuscularly IM once daily for 5 days) and 31 with Aztreonam (50-70 mg/kg/dose every 8 hours IM for 7 days). There were no clinical or microbiological failures in any of the groups. However, there was an 5\%-6\% relapse rate in each of the treatment groups. In a subsequent open trial, Cefixime ( $20 \mathrm{mg} / \mathrm{kg} /$ dose given orally once daily for 8 days) was administered to 60 children $3-16$ years with culture proven multi-drug resistant $\mathrm{S}$. typhi. 95\% (57/60) of the children had clinical and microbiological cure and only 1 patient had a relapse within 4 weeks after completion of therapy. Cefixime was well tolerated by all children. These studies indicate that cefixime is an effective alternative for the treatment of typhoid fever in children.
\end{abstract}

U.S. Naval Medical Research Unit No.3 Abbassia Fever Hospital Cairo, Egypt. 